\title{
Sprawozdanie $z$ debat poświęconych nowej książce Rafała Ziemkiewicza o Józefie Piłsudskim (Warszawa, 12 maja 2017 r.; Lódź, 17 maja 2017 r.)
}

W dniach 12 maja 2017 r. w warszawskim studenckim klubie Hybrydy przy ulicy Złotej i 17 maja 2017 r. w łódzkiej siedzibie Stowarzyszenia Robotników Chrześcijańskich przy ulicy Tuwima odbyły się dwie debaty poświęcone książce znanego publicysty, pisarza i dziennikarza Rafała Ziemkiewicza pt. Złowrogi cień Marszałka. Obok samego Autora i licznej publiczności w obydwu dyskusjach uczestniczyli zaproszeni przez R. Ziemkiewicza goście. Na debacie warszawskiej stawili się: dyrektor Wojskowego Biura Historycznego im. generała broni Kazimierza Sosnkowskiego i członek Kolegium Instytutu Pamięci Narodowej, dr Sławomir Cenckiewicz; historyk z Uniwersytetu Łódzkiego, prof. nadzw. dr hab. Przemysław Waingertner; publicysta i dziennikarz Rafał Otoka-Frackiewicz oraz znany polski aktor Roch Siemianowski. Spotkanie prowadził dziennikarz i socjolog, odpowiedzialny za popularny portal superhistoria.pl, Marcin Bartnicki. W łódzkiej debacie uczestniczył politolog i historyk z Uniwersytetu Jana Kochanowskiego w Kielcach, prof. nadzw. dr hab. Arkadiusz Adamczyk, a prowadził ją Zbigniew Natkański - szef łódzkiego oddziału Stowarzyszenia Dziennikarzy Polskich, obecnie dyrektor biura wojewody łódzkiego.

Podczas obydwu spotkań dyskusja - wzbogacona w czasie debaty warszawskiej prezentacją wybranych fragmentów książki, odczytywanych przez R. Siemianowskiego - toczyła się wokół trzech podobnych zagadnień, zaproponowanych przez M. Bartnickiego i Z. Natkańskiego: roli, znaczenia i próby oceny dokonań Józefa Piłsudskiego i Romana Dmowskiego w okresie zaborów, I wojny światowej oraz walki zbrojnej i dyplomatycznej o granice Drugiej 
Rzeczypospolitej; kształtowania się w Polsce międzywojennej swoistego „kultu” postaci Marszałka jako „ojca niepodległości” i „męża opatrznościowego", mającego dokonać po przewrocie majowym sanacji państwa; wreszcie - współczesnego wpływu mitu J. Piłsudskiego na myśl polityczna polskich elit i zachowania polityczne Polaków.

W trakcie debat $z$ negatywna ocena działalności politycznej i wojskowej przywódcy Polskiej Partii Socjalistycznej, Komendanta Strzelców, Brygadiera, wreszcie Naczelnika Państwa i Pierwszego Marszałka w latach zaborów, Wielkiej Wojny i zmagań o granice Polski; antyrepublikańskiego mitu Wodza w okresie międzywojennym, a także piętna, jakie legenda Piłsudskiego miałaby odcisnąć w mentalności współczesnych polskich polityków i społeczeństwa, polemizowali zaproszeni goście. Sławomir Cenckiewicz podkreślił, że niedoceniana najczęściej zasługa J. Piłsudskiego było „wychowanie" pokolenia utalentowanych polityków i działaczy społecznych, jak np. Ignacy Matuszewski i Tadeusz Katelbach. Z kolei P. Waingertner wskazał, że trwały w XX stuleciu, opierający się próbom sfalsyfikowania mit Marszałka był przede wszystkim wynikiem jego autentycznej charyzmy politycznej, prowadzonej przez niego skutecznej polityki oraz sukcesów, jakie osiagnął w dyplomacji i w czasie wojny, natomiast w niewielkim stopniu stanowił rezultat propagandy obozu sanacyjnego. Rafał Otoka-Frackiewicz podnosił fakt tyleż naturalnego i usprawiedliwionego rolą odegraną przez J. Piłsudskiego i R. Dmowskiego w procesie odzyskiwania przez Polskę niepodległości po I wojnie światowej, co mylącego zestawiania postaci „ojców Drugiej Rzeczypospolitej” - Marszałka stanowiącego przykład polityka-praktyka i pragmatyka oraz ideologa i teoretyka, jakim był, jego zdaniem, twórca polskiej myśli narodowej. W trakcie łódzkiego spotkania A. Adamczyk wskazał ponadto m.in. na dezawuowanie przez R. Ziemkiewicza niewątpliwych osiagnięć obozu pomajowego - kierowanego przez J. Piłsudskiego, a później jego następców - w dziedzinie modernizacji polskiej gospodarki oraz rozwoju sił zbrojnych Rzeczypospolitej.

W trakcie obydwu dyskusji liczne pytania autorowi książki i polemizującym $z$ nim gościom zadawała również publiczność. Debaty zakończyły spotkania R. Ziemkiewicza $z$ admiratorami jego publicystyki historycznej, którzy mogli uzyskać autograf Autora na egzemplarzach jego najnowszej książki.

PrZemystaw Waingertner UNIWERSYTET ŁÓDZKI*

* Wydział Filozoficzno-Historyczny, Instytut Historii, Katedra Historii Polski Najnowszej, e-mail: wajn@op.pl. 